\title{
Catecholamines Can Induce Pulmonary Remodeling in Rats
}

\author{
Beate Rassler ${ }^{a}$ Grit Marx ${ }^{a}$ Katrin Schierle ${ }^{b}$ Heinz-Gerd Zimmer

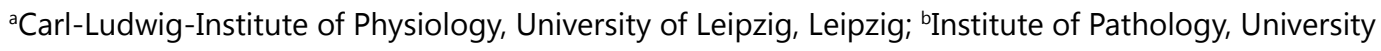 \\ Hospital of Leipzig, Leipzig
}

\section{Key Words}

Norepinephrine $\cdot$ Phenylephrine $\cdot$ Isoproterenol $\bullet$ Pulmonary extracellular matrix $\bullet$ Collagen • Matrix metalloproteinase- 2 - Transforming growth factor- $\beta \cdot$ Pulmonary fibrosis

\begin{abstract}
Background/Aims: Previously, we found that catecholamine (CA) infusion in rats induced pulmonary injury with edema and inflammation resembling acute lung injury in humans. Here, we examined effects of norepinephrine (NE) and of selective $\alpha$ - and $\beta$-adrenergic agonists on the remodeling of pulmonary extracellular matrix. Methods: Eighty rats were infused over 8-72 h with $\mathrm{NE}$, phenylephrine (PE), isoproterenol (ISO) or $\mathrm{NaCl}$ solution. We investigated mRNA expression of collagen, matrix metalloproteinase (MMP)-2, its tissue inhibitor (TIMP-2) and transforming growth factor (TGF)- $\beta$ isoforms in lung tissue. Additionally, lung histology, hemodynamic function and cardiac hypertrophy were evaluated. Results: After $72 \mathrm{~h}$ of infusion, lung histology showed beginning fibrosis and vascular hypertrophy. Collagen type I, MMP-2 and TIMP-2 mRNA expression were significantly elevated. All these effects were most pronounced with NE while PE and ISO induced weaker responses. TGF- $\beta$ mRNA expression was also elevated after $72 \mathrm{~h}$, predominantly after PE infusion. Cardiac hypertrophy was most pronounced after ISO infusion. Conclusion: CA infusion over $72 \mathrm{~h}$ may induce pulmonary remodeling. Mainly $\alpha$-adrenergic but also $\beta$-adrenergic mechanisms contribute to these processes. In contrast, cardiac hypertrophy is predominantly mediated by $\beta$-adrenergic stimulation and hence, is considered to be a direct adrenergic effect rather than a consequence of pulmonary fibrosis.
\end{abstract}




\section{Introduction}

Enhanced sympathetic activation or increased plasma catecholamine (CA) levels play a pivotal role in several types of pulmonary edema such as neurogenic pulmonary edema or pulmonary edema in patients with pheochromocytoma. Elevated levels of circulating norepinephrine (NE) have also been suggested to be involved in the pathogenesis of the acute respiratory distress syndrome (ARDS) $[1,2]$. Previously, we demonstrated that continuous intravenous CA infusion in rats caused fluid shifts in the lung with formation of pulmonary edema and pleural effusion [3,4]. Edema appeared less than one hour after starting the infusion with NE or phenylephrine (PE) and was considered to be initiated by increased right ventricular systolic pressure (RVSP) and total peripheral resistance (TPR) [5]. The fluid shifts occurred earlier and were more serious with $\alpha$-adrenergic stimulation; after a few hours of PE infusion we observed severe, protein-rich alveolar edema. Histology of these lungs strongly resembled the acute lung injury (ALI) or ARDS in humans. In contrast, edema was delayed and less pronounced after treatment with $\beta$-adrenergic substances such as isoproterenol (ISO) [4]. Inflammation developed in parallel with lung edema with all types of adrenergic stimulation. After three days of infusion, edema gradually disappeared, and first signs of vascular hypertrophy and pulmonary fibrosis emerged [5].

A pathogenesis consisting of exudative, proliferative and fibrotic stages is typical for human ALI/ARDS. The etiology of ALI/ARDS is manifold, but severe inflammatory reactions play a pivotal role. For a long time, fibrosis in this serious lung disease has been considered to be a consequence of the severe inflammation. More recent findings, however, suggested that the first profibrotic changes occur very early - already during the exudative phase in parallel with development of inflammation $[6,7]$. Numerous proinflammatory cytokines such as tumor necrosis factor $\alpha$ and interleukin-1 $\beta$ also exert profibrotic effects [8]. Edema fluid of ALI patients has been shown to mediate inflammation and fibroblast proliferation [9]. Conversely, mediators of ECM remodeling, especially MMP-2 and MMP-9, have been suggested to contribute to the increase of alveolar-capillary permeability and hence, to aggravation of edema in ALI/ARDS $[10,11]$. These findings indicate that edematous, inflammatory and fibrotic processes are intrinsically linked. Transition into a fibrotic stage might also be expected in other conditions with pulmonary edema and inflammation such as lung injuries induced by strong sympathetic activation or stimulation with adrenergic agonists.

Pulmonary fibrosis is a consequence of abnormal accumulation of proteins of the extracellular matrix (ECM). Matrix metalloproteinases (MMPs) and their specific tissue inhibitors (TIMPs) play a crucial role in ECM remodeling. Among them, gelatinases MMP-2 and MMP-9 which degrade denatured collagens (gelatin) but also native type IV collagen, and their specific tissue inhibitors have particular importance. Many cytokines, growth factors, hormones and other signals regulate synthesis, secretion, activation and inhibition of MMPs (for reviews see $[12,13]$ ). Transforming growth factor- $\beta$ (TGF- $\beta$ ) promotes ECM synthesis and deposition through its effects on MMPs and TIMPs $[14,15]$ and hence, is considered to be a key mediator in fibrogenic diseases such as pulmonary fibrosis [16, 17]. Catecholamines are also involved in the regulation of the MMP/TIMP system [18]. In the myocardium, NE promotes cardiac fibrosis by stimulating collagen synthesis $[19,20]$. Fourteen days of continuous NE infusion in rats induced transient increases in MMP-2 and TIMP-2 expression and, finally, enhanced collagen deposition in the heart [21].

The main purpose of the present study was to examine whether continuous CA infusion over three days induces ECM remodeling in the lungs of normal rats. We compared the effects of NE, the physiological sympathetic transmitter, with those of the selective $\alpha$ - and $\beta$-adrenergic agonists phenylephrine (PE) and isoproterenol (ISO), respectively. We evaluated lung histology as well as mRNA expression and protein concentration of several ECM components such as collagen, MMP-2, TIMP-2 and TGF- $\beta$ isoforms. In addition, hemodynamic parameters and heart weight were measured to document the effectiveness of 
adrenergic stimulation and to elucidate the relationship between direct adrenergic effects, altered hemodynamic conditions, enhanced pulmonary remodeling and cardiac, especially right ventricular, hypertrophy.

\section{Materials and Methods}

\section{Animals and treatment}

The experiments were performed on 88 female Sprague-Dawley rats supplied by Charles River (Sulzfeld, Germany). The animals were maintained in accordance with the "Principles of laboratory animal care" (NIH publication No. 86-23, revised 1985) as well as with the German Law on the Protection of Animals. The experiments were approved by the appropriate Federal State Agency.

The body weight of the animals was $210-260 \mathrm{~g}$ at the beginning of the study. The main group of animals $(\mathrm{n}=80)$ received intravenous infusion of NE $\left(0.1 \mathrm{mg} \mathrm{kg}^{-1} \mathrm{~h}^{-1}, \mathrm{n}=23\right)$, PE $\left(0.5 \mathrm{mg} \mathrm{kg}^{-1} \mathrm{~h}^{-1}, \mathrm{n}=18\right)$, ISO (0.024 $\left.\mathrm{mg} \mathrm{kg}^{-1} \mathrm{~h}^{-1}, \mathrm{n}=17\right)$ or sodium chloride $0.9 \%$ as control $(\mathrm{C}, \mathrm{n}=22)$. A second group of 8 animals was infused for $72 \mathrm{~h}$ with NE $\left(0.1 \mathrm{mg} \mathrm{kg}^{-1} \mathrm{~h}^{-1}\right)$ plus the $\beta$-adrenergic antagonist propranolol (PR, $1.0 \mathrm{mg} \mathrm{kg}^{-1}$ $\left.\mathrm{h}^{-1}, \mathrm{n}=4\right)$ or with NE $\left(0.1 \mathrm{mg} \mathrm{kg}^{-1} \mathrm{~h}^{-1}\right)$ plus the $\alpha$-adrenergic antagonist prazosin (PZ, $\left.0.1 \mathrm{mg} \mathrm{kg}^{-1} \mathrm{~h}^{-1}, \mathrm{~h}=4\right)$. The drug doses were chosen according to previous experience [4, 21-23]. All drugs with the exception of PZ (Pfizer, Karlsruhe, Germany) were obtained from Sigma-Aldrich (Deisenhofen, Germany). The infusions were administered with automatic pumps (Infors AG, Basel, Switzerland) at a rate of $4 \mathrm{ml} \mathrm{kg}^{-1} \mathrm{~h}^{-1}$ via an infusion catheter (Vygon, Aachen, Germany). In the main group, animals were infused over time intervals of $8,16,24$ and $72 \mathrm{~h}$ with each subgroup containing 4-7 animals. During this time, the animals were allowed to move freely in their cages with access to tap water and rat chow diet (Altromin C100, Altromin GmbH, Lage, Germany).

\section{Hemodynamic measurements}

At the end of the stimulation period, the animals were anaesthetized with thiopental sodium (Trapanal ${ }^{\circledR}$, Byk Gulden, Konstanz, Germany) $80 \mathrm{mg} \mathrm{kg}^{-1}$ intraperitoneally. They were tracheotomized, and a polyethylene cannula was placed in the trachea. The right ventricle (RV) and left ventricle (LV) were catheterized with Millar® (Millar Instruments, Houston, Texas, USA) ultraminiature catheter pressure transducers (for more details see [3]) to measure RV (RVSP) and LV systolic pressure (LVSP). After withdrawal of the LV catheter tip into the aorta, diastolic aortic pressure (DAP) was measured to calculate mean aortic pressure (MAP). For determination of the index of cardiac output (CI) we applied the thermodilution method using a thermosensitive $1.5 \mathrm{~F}$ microprobe and a Cardiomax II computer (Columbus Instruments, Columbus, Ohio, USA). Total peripheral resistance (TPR) was calculated by dividing MAP by CI.

\section{Sampling of materials}

After completing the hemodynamic measurements, the abdominal cavity was opened and a cannula was inserted in the abdominal aorta to withdraw blood. Then we opened the chest wall and pipetted fluid from the pleural space if present. The animals died during these procedures. Breathing ceased with opening of the chest while the heart continued beating for some minutes. The heart was rapidly excised, the RV free wall was trimmed away, and both ventricles were separately weighed. RV and LV weights were normalized to baseline body weight (RVW/BW, LVW/BW) and served as indices of hypertrophy. We also excised the lungs and took pieces from all lung lobes for further analyses. A part of the lung samples from both animal groups was fixed in formalin for histological examination. Other lung pieces were frozen in liquid nitrogen and stored at $-80{ }^{\circ} \mathrm{C}$. Biochemical analyses on these lung pieces were performed only in the main group.

\section{Histology}

Representative tissue areas of all lung lobes were fixed in formalin and embedded in paraffin. All slices ( $8 \mu \mathrm{m}$ thick) were stained with hematoxylin-eosin (HE) and Elastica van Gieson (EvG). They were assessed with respect to occurrence of peribronchial and interstitial fibrosis and of vascular hypertrophy by a pathologist (K.S.) who was blinded towards the treatment of the animals. For presentation, we chose typical examples which were observed in all preparations of the same treatment. 


\begin{tabular}{rl|l} 
Cellular Physiology & Cell Physiol Biochem 2012;30:1134-1147 \\
\cline { 2 - 2 } and Biochemistry & $\begin{array}{l}\text { DOI: 10.1159/000343304 } \\
\text { Published online: October 05, 2012 }\end{array}$ & $\begin{array}{l}\text { O 2012 S. Karger AG, Basel } \\
\text { www.karger.com/cpb }\end{array}$ \\
\cline { 2 - 3 } & Rassler/Marx/Schierle/Zimmer: Catecholamine-induced Pulmonary Remodeling
\end{tabular}

\section{Ribonuclease protection assay}

Ribonuclease protection assay was applied to determine mRNA levels of several molecules and regulators of the extracellular matrix (ECM) such as transforming growth factor (TGF)- $\beta$ isoforms (TGF- $\beta_{1},-\beta_{2}$ and $-\beta_{3}$ ), collagen type I (Coll1) and type III (Coll3), matrix metalloproteinase (MMP)-2 and its tissue inhibiting factor (TIMP-2) in lung tissue. For this purpose, two small pieces of lung tissue were homogenized. Total RNA was isolated with the Trizol ${ }^{\circledR}$ reagent (Gibco BRL, Karlsruhe, Germany) according to the manufacturer's protocol. The isolated mRNA was hybridized with template sets rECM- 3 and rTGF- $\beta$, respectively, and labelled with RiboQuant ${ }^{\circledR}$ In vitro Transcription Kit (Pharmingen, Hamburg, Germany) and $\left(\alpha-{ }^{32} \mathrm{P}\right)$-UTP as described by the manufacturer. Composition of the template sets was previously described [21]. For TGF- $\beta$ mRNA $10 \mu \mathrm{g}$ of total RNA, and for ECM $5 \mu \mathrm{g}$ of total RNA were used for hybridization. After overnight hybridization, the unprotected probes were digested with RNases. The protected radioactive RNA was displayed on a denaturing polyacrylamide gel and evaluated by phosphorimaging (Molecular Imager, BioRad, München, Germany). The signals of specific mRNAs were normalized to those of GAPDH.

TGF- $\beta$ ELISA

An Enzyme-Linked Immuno-Sorbent Assay (ELISA, R\&D Systems, Minneapolis, USA) was applied for the determination of TGF- $\beta$ concentration in lung tissue. This assay employs the quantitative sandwich enzyme immunoassay technique. Lung tissue was homogenized with 5-fold volume of PBS supplemented with protease inhibitor cocktail (Boehringer Mannheim, Mannheim, Germany). After 10 min of centrifugation (at $4^{\circ} \mathrm{C}, 13000 \mathrm{~g}$ ), the supernatant was activated by $2.5 \mathrm{~N}$ acetic acid with $10 \mathrm{M}$ urea at room temperature over $10 \mathrm{~min}$, then neutralized with $2.7 \mathrm{~N} \mathrm{NaOH}$ and $1 \mathrm{M} \mathrm{HEPES}$ and incubated overnight at $4^{\circ} \mathrm{C}$. The protein concentration of these activated samples was about $2.3 \mathrm{mg} / \mathrm{ml}$ as determined by BioRad Protein Assay (BioRad, München, Germany). We used $50 \mu \mathrm{l}$ or $100 \mu \mathrm{l}$ of activated sample to detect the protein concentration of TGF- $\beta_{1}$ and $-\beta_{2}$, respectively. Samples and standards were pipetted into the wells. Further procedures of sample analysis were performed according to manufacturer's instruction. The absorbance was measured at $450 \mathrm{~nm}$ with wavelength correction at $570 \mathrm{~nm}$ using a Spectra count (Packard Instruments, Illinois, USA). TGF- $\beta$ concentrations were calculated using the program i-smart (Packard Instruments, Illinois, USA) with a 4-parameter regression curve fitting. The minimum detectable TGF- $\beta$ concentration was $31.2 \mathrm{pg} / \mathrm{ml}$, the maximum concentration for accurate determination was $2000 \mathrm{pg} / \mathrm{ml}$.

\section{Preparation of lung tissue extract and MMP zymography}

Lungs from animals infused over $24 \mathrm{~h}$ and $72 \mathrm{~h}$ were used for MMP zymography. Extracellular proteins of approximately $25 \mathrm{mg}$ frozen lung tissue were extracted with 20 -fold volume of extraction buffer $(10 \mathrm{mM}$ Tris-Cl pH 7.5, $150 \mathrm{mM} \mathrm{NaCl}, 20 \mathrm{mM} \mathrm{CaCl}, 1 \mu \mathrm{MnSO}_{4}, 0.01 \%$ (v/v) Triton X-100, 0.015\% $\mathrm{NaN}_{3}, 0.5 \mathrm{mM}$ PMSF) overnight at $4^{\circ} \mathrm{C}$. The protein extracts contained about $2.5 \mathrm{mg} / \mathrm{ml}$ protein (BioRad Protein assay, BioRad, München, Germany).

Measurement of pulmonary MMP activity in the gel was performed corresponding to the method previously applied in rat myocardium $[21,24]$. In brief, gelatine $(0.1 \%$ (w/v), Merck, Darmstadt, Germany) was added to standard Laemmli acrylamide polymerization mixture. Tissue extract was mixed 1:3 with substrate gel sample buffer (10\% (w/v) SDS, $4 \%(\mathrm{w} / \mathrm{v})$ sucrose, $0.25 \mathrm{mM}$ Tris-Cl pH 6.8, and $0.1 \%(\mathrm{w} / \mathrm{v})$ bromphenol blue). About $8 \mu \mathrm{g}$ of the extracted protein were loaded immediately without boiling. Gels were run at $20 \mathrm{~mA}$ at $4^{\circ} \mathrm{C}$. After electrophoresis, the gels were soaked in $2.5 \%(\mathrm{w} / \mathrm{v})$ Triton X-100, incubated overnight at $37^{\circ} \mathrm{C}$ in substrate buffer $\left(50 \mathrm{mM}\right.$ Tris-Cl pH $8.0,8 \mathrm{mM} \mathrm{CaCl}{ }_{2}$, and $0.1 \mathrm{nM} \mathrm{ZnSO}_{4}$, and stained for $15-30 \mathrm{~min}$ in $0.25 \%(\mathrm{w} / \mathrm{v}$ ) Coomassie Blue R-250 in acetic acid, methanol and water (ratio by volume $1: 4.5: 4.5$ ). Then they were destained in $10 \%$ acetic acid and $5 \%$ methanol, and scanned for lysis band intensity. Lysis band intensity served to estimate the collagenase activity (semiquantified by reverse-image densitometry). A gelatinase zymography standard (human MMP-2, Chemicon, Hofheim, Germany) was used to detect the correct band.

\section{Statistical analysis}

Data are expressed as mean \pm SEM. A multiple-sample comparison (one-way ANOVA and multiple range test using the criterion of the least significant differences) was applied to test the differences between the groups representing the different kinds and time intervals of infusion. A value of $\mathrm{P}<0.05$ was considered to be significant. 
Fig. 1. Histological preparations of rat lungs, stained with Elastica van Gieson a) control $(72 \mathrm{~h}$ infusion with $0.9 \%$ $\mathrm{NaCl}$ solution): normal lung tissue without patho-histological alterations; b) $\mathrm{NE}$ ( $72 \mathrm{~h}$ infusion with $0.1 \mathrm{mg} \mathrm{kg}^{-1} \mathrm{~h}^{-1}$ norepinephrine): moderate to severe peribronchial fibrosis (black arrow), moderate vascular hypertrophy (white arrow); c) PE (72 h infusion with 0.5 $\mathrm{mg} \mathrm{kg}^{-1} \mathrm{~h}^{-1}$ phenylephrine): moderate peribronchial fibrosis (black arrow), moderate vascular hypertrophy (white arrow); d) ISO (72 $\mathrm{h}$ infusion with $0.024 \mathrm{mg} \mathrm{kg}^{-1} \mathrm{~h}^{-1}$ isoproterenol): mild peribronchial fibrosis (black arrow), mild vascular hypertrophy (white arrow); e) NE+PR (72 h infusion with $0.1 \mathrm{mg} \mathrm{kg}^{-1} \mathrm{~h}^{-1}$ norepinephrine plus $1.0 \mathrm{mg} \mathrm{kg}^{-1} \mathrm{~h}^{-1}$ propranolol): mild peribronchial fibrosis (black arrow), moderate vascular hypertrophy (white arrow); f) NE+PZ (72 h infusion with $0.1 \mathrm{mg} \mathrm{kg}^{-1} \mathrm{~h}^{-1}$ norepinephrine plus $0.1 \mathrm{mg} \mathrm{kg}^{-1} \mathrm{~h}^{-1}$ prazosin): moderate peribronchial fibrosis (black arrow), mild to moderate vascular hypertrophy (white arrow). All slices are presented in original magnification $* 20$.

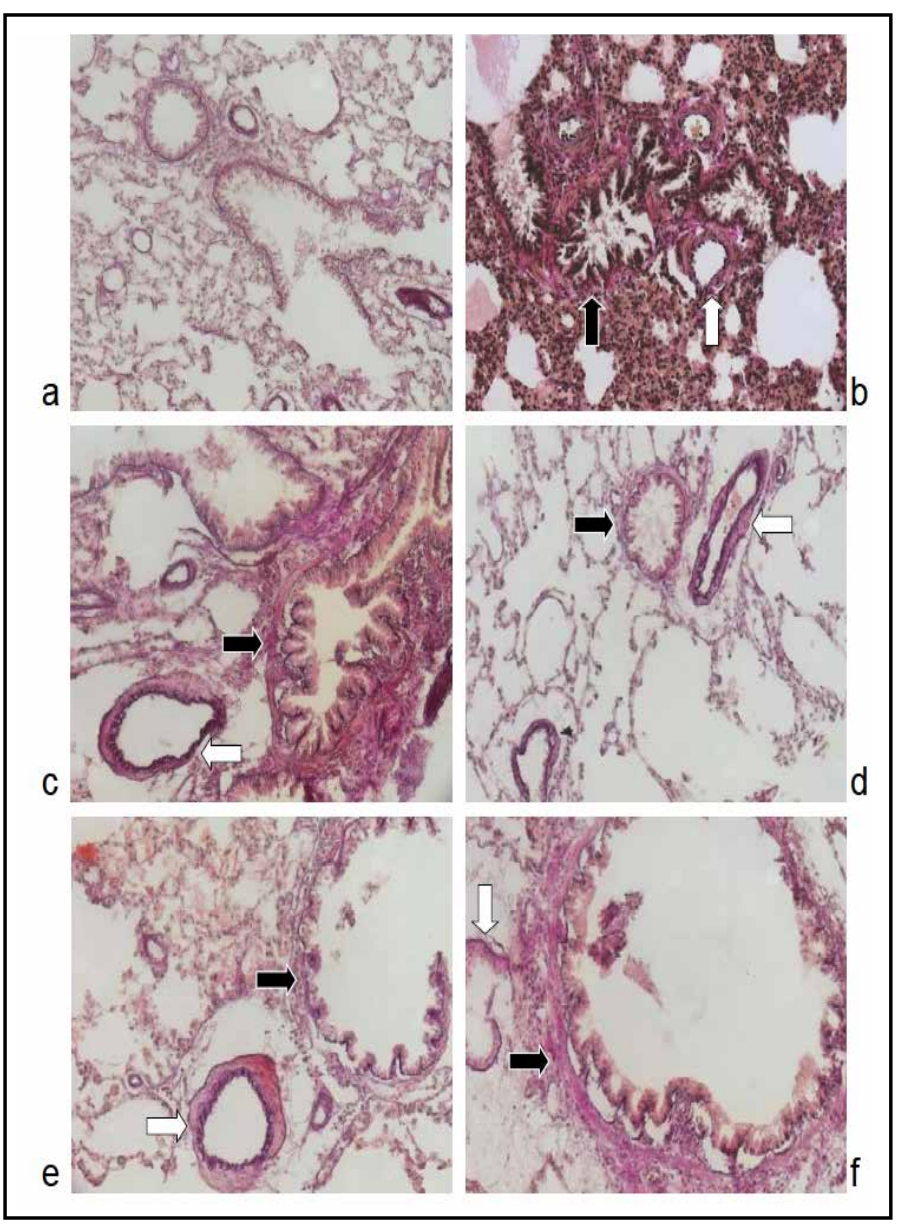

\section{Results}

\section{Pulmonary changes}

Pleural fluid. In the chest cavity of control animals, we found only minuscule amounts of pleural fluid (PF, less than $0.1 \mathrm{ml}$ on average). Animals treated with PE presented $0.80 \pm$ 0.31 and $1.1 \pm 0.78 \mathrm{ml}$ of PF after 8 and $16 \mathrm{~h}$, respectively, but PF disappeared with longer stimulation. Significant amounts of PF were observed after $16 \mathrm{~h}$ of NE $(1.8 \pm 0.69 \mathrm{ml})$ and 24 $\mathrm{h}$ of ISO infusion $(6.2 \pm 2.23 \mathrm{ml}$; $\mathrm{P}<0.001)$.

Histology. After 8-24 h of NE and PE infusion, lung histology presented with interstitial and alveolar edema and inflammation. With ISO, interstitial edema and inflammation developed after $16 \mathrm{~h}$ of infusion. These results corresponded with findings from previous studies $[4,5]$. After $72 \mathrm{~h}$ of CA infusion, there were just a few residuals of edema but we found signs of a beginning peribronchial and interstitial fibrosis and mild vascular hypertrophy. These symptoms were most pronounced with NE treatment. Lungs from animals treated with PE or ISO showed a milder degree of peribronchial fibrosis and vascular hypertrophy, and this was similar after infusion of NE plus PR or NE plus PZ (Fig. 1a-f).

Extracellular matrix components. The mRNA expression of collagen type I (Coll1) increased significantly $(\mathrm{P}<0.001)$ after $72 \mathrm{~h}$ of stimulation with all types of CAs (Fig. 2a). This effect was most pronounced with NE (5.5fold of C). In contrast, Coll3 mRNA increased only insignificantly $(\mathrm{P}=0.09$; Fig. $2 \mathrm{~b})$. NE also stimulated the mRNA expression of MMP-2 and of its tissue inhibitor TIMP-2 (P < 0.001; Fig. 2c, d). Additionally, we observed activation of MMP-2 protein after $72 \mathrm{~h}$ of NE but not after ISO or PE infusion (Fig. 3). PE and ISO effects 


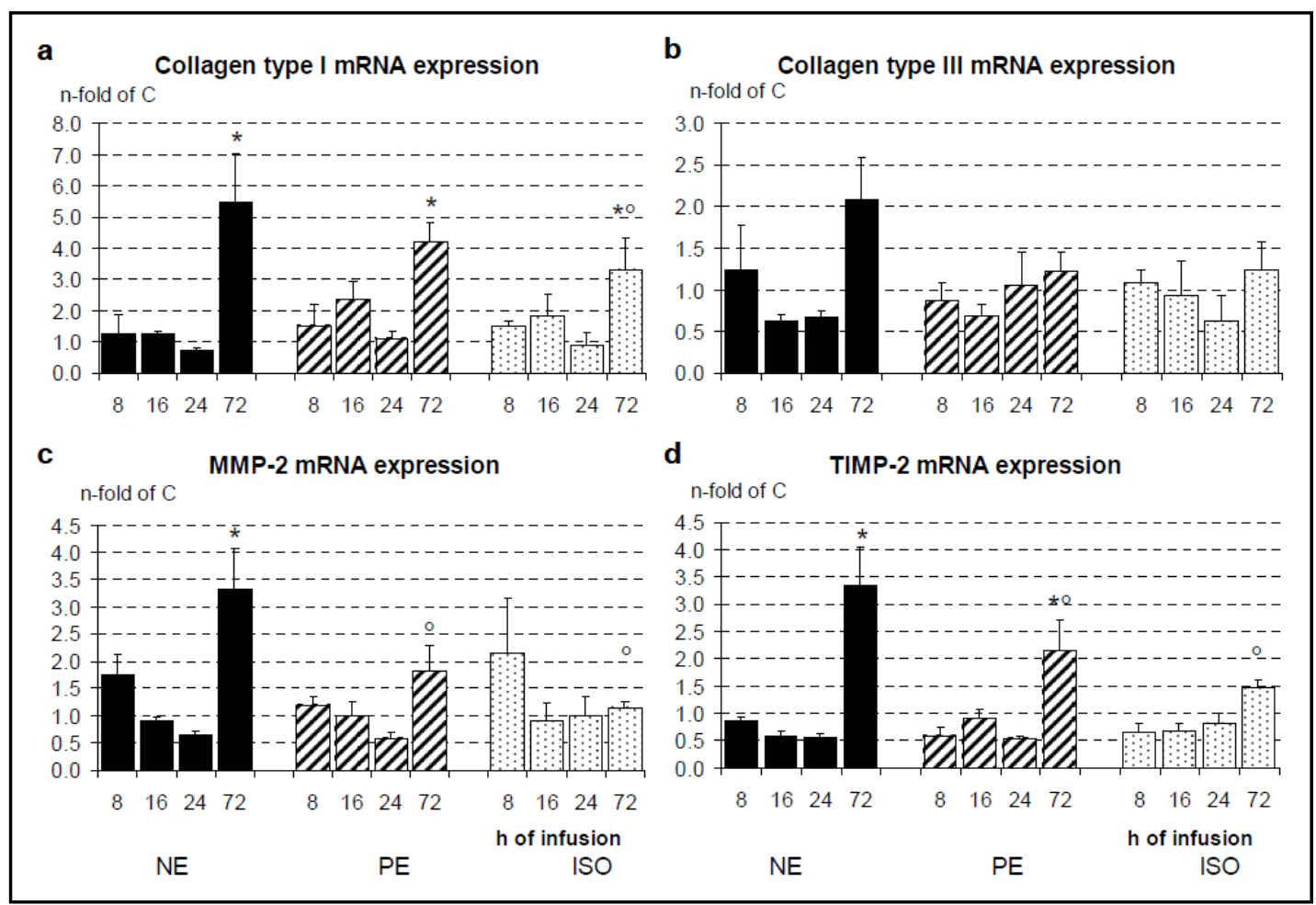

Fig. 2. mRNA expression of a) collagen type I (Coll1), b) collagen type III (Coll3), c) matrix metalloproteinase-2 (MMP-2) and d) tissue inhibitor of MMP-2 (TIMP-2) in lung tissue after infusion over 8, 16, 24 or $72 \mathrm{~h}$ with $\mathrm{NaCl}$ (control, $\mathrm{C} ; \mathrm{n}=5,5,5,5$ for 8, 16, 24 and $72 \mathrm{~h}$, respectively), norepinephrine (NE; $\mathrm{n}=4,5,6,7$ ), phenylephrine (PE; $\mathrm{n}=4,4,4,5$ ) or isoproterenol (ISO; $\mathrm{n}=4,4,4,5)$. Values are expressed as ratio to control (means + SEM, C = 1.0). Statistic results and significance marks: ANOVA: Coll1: $\mathrm{P}<0.001$; Coll3: $\mathrm{P}=0.09$; MMP-2: $\mathrm{P}<0.001$; TIMP-2: $\mathrm{P}<0.001{ }^{*}$ significant vs. time-corresponding $\mathrm{C} ;{ }^{\circ}$ ISO and PE significant vs. time-corresponding NE.

Fig. 3. Relative abundance of matrix metalloproteinase-2 (MMP-2) activity in lung tissue obtained from zymography. Animals were infused over 24 or $72 \mathrm{~h}$ with $\mathrm{NaCl}$ (control, C; $\mathrm{n}=5,5$ for 24 and $72 \mathrm{~h}$, respectively), norepinephrine (NE; $\mathrm{n}=$ 6,7 ), phenylephrine (PE; $n=4,5$ ) or isoproterenol (ISO; $n=4,5$ ). Values are expressed as ratio to control (means + SEM). Statistic results and significance marks: ANOVA: $\mathrm{P}=0.005$; ${ }^{*}$ significant vs. timecorresponding $\mathrm{C}$; ${ }^{\circ}$ ISO and PE significant vs. timecorresponding NE.

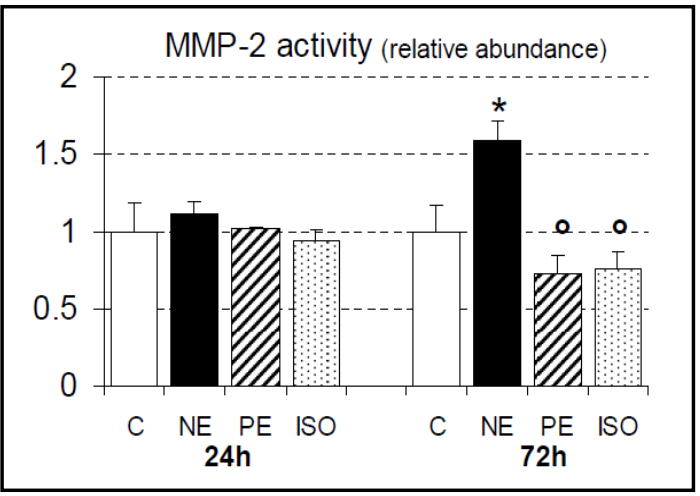

on Coll1 and TIMP-2 mRNA were similar to those of NE but less pronounced. No significant effects were exerted on Coll3 and MMP-2 (cf. Fig. 2a-d).

CA infusion over $72 \mathrm{~h}$ also induced an increase in mRNA expression of TGF- $\beta$ isoforms. The most pronounced effect was exerted by PE (TGF- $\beta_{1}: 5.7$ fold, TGF- $\beta_{2}: 4.4$ fold, TGF- $\beta_{3}$ : 3.3 fold of $\mathrm{C}$; $\mathrm{P}<0.001$ ), while NE had a rather weak effect on TGF- $\beta$ isoforms (Fig. 4). The protein concentration of TGF- $\beta_{2}$ was also significantly elevated after $72 \mathrm{~h}$ of treatment with PE and ISO, but not after NE infusion. TGF- $\beta_{1}$ protein did not show any significant difference (Fig. 5). 


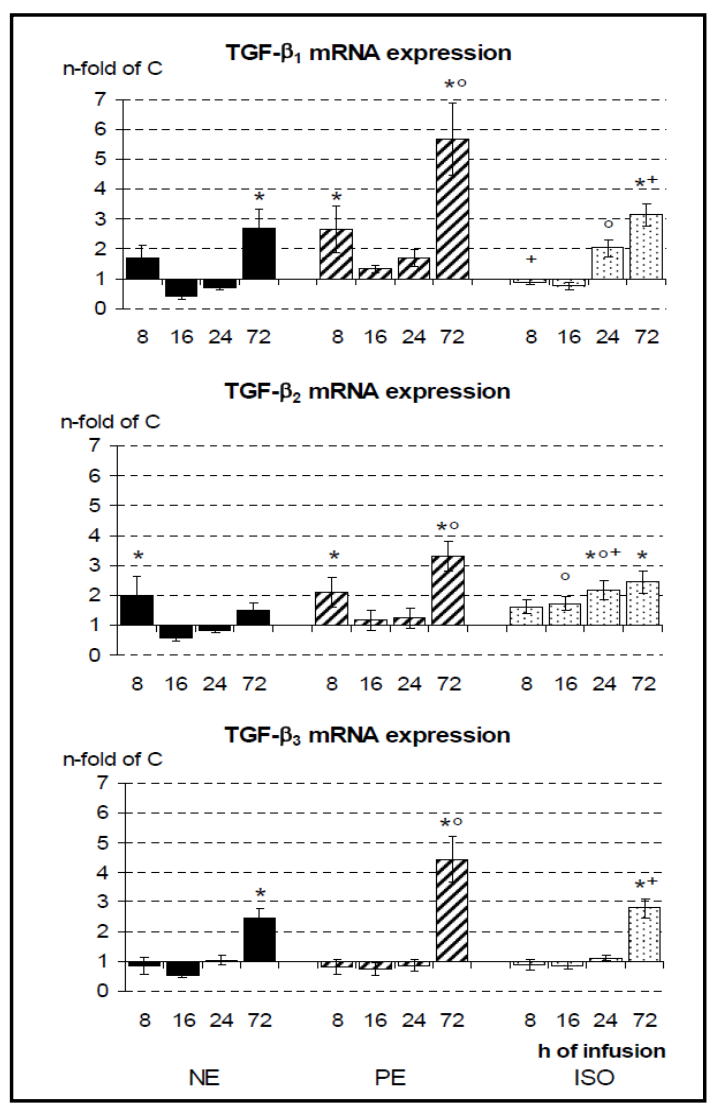

Fig. 4. Transforming growth factor (TGF)- $\beta_{1}$, $-\beta_{2}$ and $-\beta_{3}$ mRNA expression in lung tissue after infusion over $8,16,24$ or $72 \mathrm{~h}$ with $\mathrm{NaCl}$ (control, $\mathrm{C} ; \mathrm{n}=5,5,5,5$ for $8,16,24$ and $72 \mathrm{~h}$, respectively), norepinephrine (NE; $n=4,5,6,7$ ), phenylephrine (PE; $\mathrm{n}=4,4,4,5$ ) or isoproterenol (ISO; $\mathrm{n}=4,4,4$, $5)$. Values are expressed as ratio to control (means + SEM, C $=1.0$ ). Statistic results and significance marks: ANOVA: $\mathrm{P}<0.001$ for all three isoforms; * significant vs. time-corresponding C; ${ }^{\circ}$ ISO and PE significant vs. time-corresponding $\mathrm{NE}$; ${ }^{+}$ISO significant vs. timecorresponding PE.

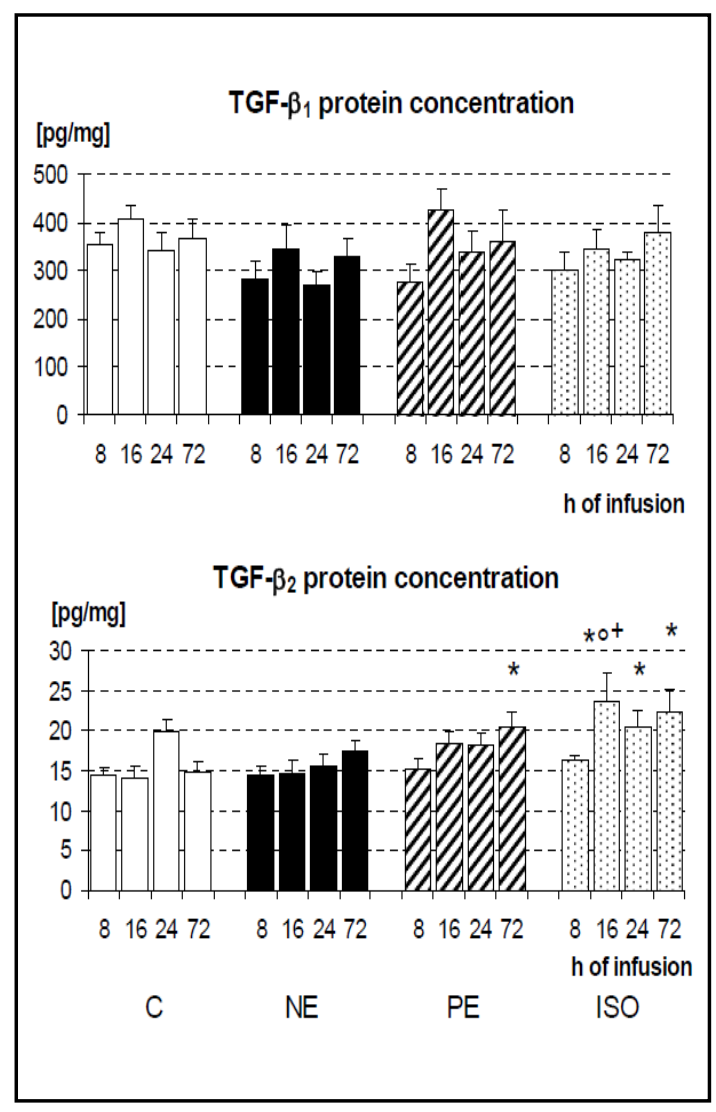

Fig. 5. Transforming growth factor (TGF)- $\beta_{1}$ and $-\beta_{2}$ protein concentration (means + SEM) in lung tissue after infusion over $8,16,24$ or $72 \mathrm{~h}$ with $\mathrm{NaCl}$ (control, $\mathrm{C} ; \mathrm{n}=6,6,5,5$ for 8, 16, 24 and $72 \mathrm{~h}$, respectively), norepinephrine (NE; $n=4,6,6$, 7 ), phenylephrine (PE; $n=5,4,4,5$ ) or isoproterenol (ISO; $n=4,4,4,5$ ). Statistic results and significance marks: ANOVA: TGF- $\beta_{1}$ : $\mathrm{P}=0.28$; TGF- $\beta_{2}$ : $\mathrm{P}<0.001$; ${ }^{*}$ significant vs. time-corresponding $\mathrm{C}$; ${ }^{\circ}$ ISO and $\mathrm{PE}$ significant vs. time-corresponding $\mathrm{NE}$; + ISO significant vs. time-corresponding PE.

\section{Hemodynamic changes and cardiac hypertrophy}

Stimulation with NE caused a significant increase in RVSP by more than $100 \%$ through all stimulation intervals $(\mathrm{P}<0.001)$, while LVSP remained at control level (Fig. 6a and b). In

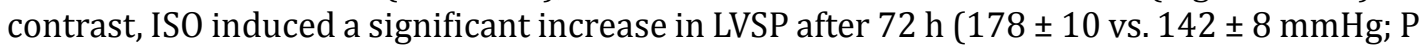
$<0.001$ ), but only a transient RVSP elevation after $8 \mathrm{~h}$ of infusion ( $54 \pm 4 \mathrm{vs.} 33 \pm 2 \mathrm{mmHg}$; $\mathrm{P}$ $<0.001$ ). The latter was accompanied by reduction of DAP from $92 \pm 7$ to $76 \pm 12 \mathrm{mmHg}$ (Fig. $6 c)$ and a significant increase of heart rate from $384 \pm 24$ to $493 \pm 14 \mathrm{~min}^{-1}(\mathrm{P}<0.001$; Fig. 6d). Throughout all stimulation intervals with ISO, CI was almost or even more than twice as high as in controls $(\mathrm{P}<0.001$; Fig. $6 \mathrm{e})$. The hemodynamic response to $72 \mathrm{~h}$ of infusion with $\mathrm{NE}+\mathrm{PZ}$ was not significantly different from the correspondent ISO infusion (LVSP 156 $\pm 4 \mathrm{mmHg}$; RVSP $46 \pm 6$ vs. $45 \pm 9 \mathrm{mmHg}$ with ISO; CI $355 \pm 34$ vs. $351 \pm 23 \mathrm{ml} \mathrm{min}^{-1} \mathrm{~kg}^{-1}$ with ISO; TPR $0.41 \pm 0.04$ vs. $0.45 \pm 0.04 \mathrm{mmHg}$ min $\mathrm{kg} \mathrm{ml}^{-1}$ with ISO; data not shown). In contrast, CI remained low with NE, since NE provoked a transient increase in TPR after $8 \mathrm{~h}$ 
Fig. 6. Hemodynamic results (only data from the main animal group are presented): a) right (RVSP) and b) left ventricular systolic pressure (LVSP), c) diastolic aortic pressure (DAP), d) heart rate (HR), e) cardiac index and f) total peripheral resistance (TPR); animals were infused over $8,16,24$ or $72 \mathrm{~h}$ with $\mathrm{NaCl}$ (control, C; $\mathrm{n}=6,6,6,5$ for 8, 16,24 and $72 \mathrm{~h}$, respectively), norepinephrine (NE; $n=4,6$, 6,7 ), phenylephrine (PE; $n=5$, $4,4,5$ ) or isoproterenol (ISO; $\mathrm{n}=4,4,4,5$ ). Data are given as means + SEM. Statistic results and significance marks: ANOVA: $\mathrm{P}<0.001$ for all parameters; * significant vs. time-corresponding C; - ISO and PE significant vs. time-corresponding

$\mathrm{NE}$;

+ ISO significant vs. timecorresponding PE.

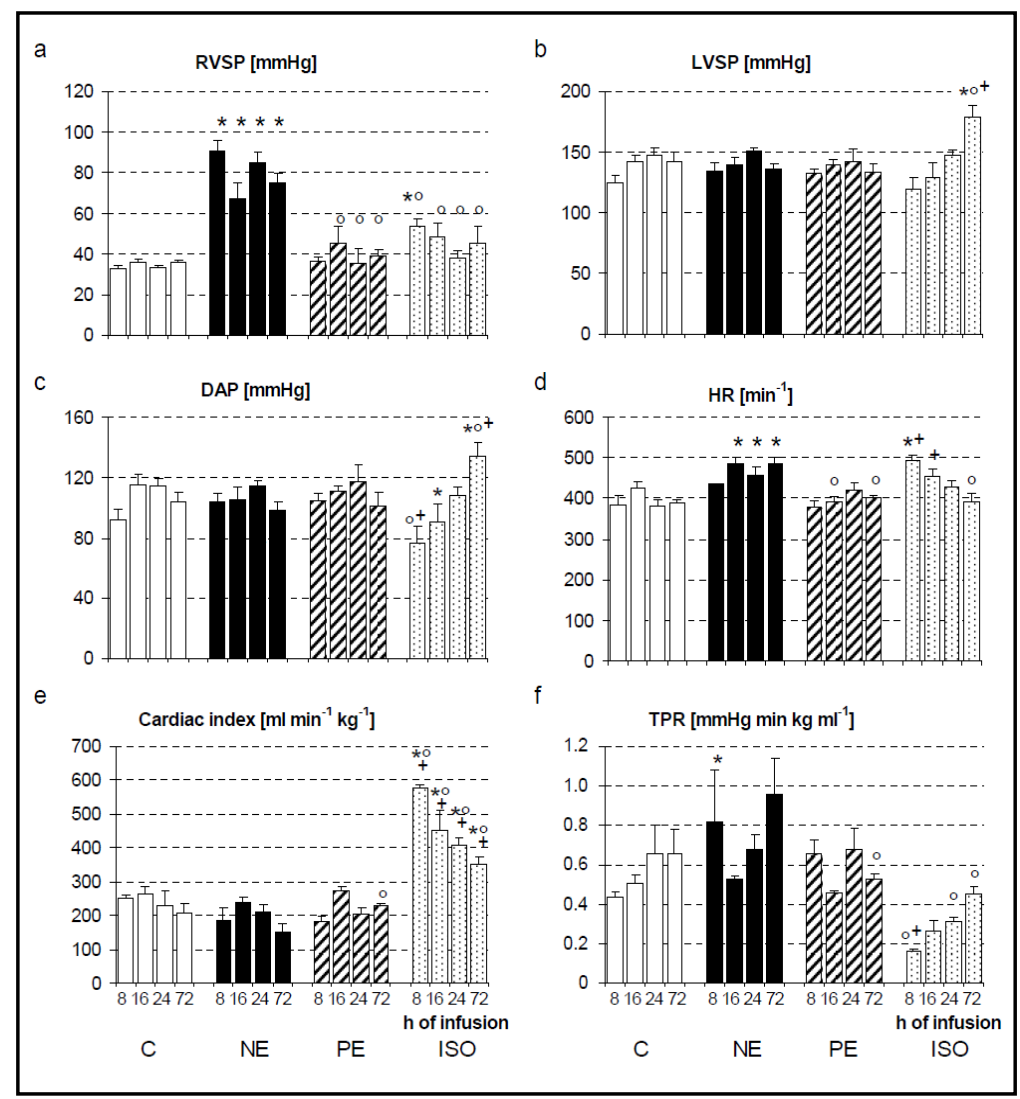

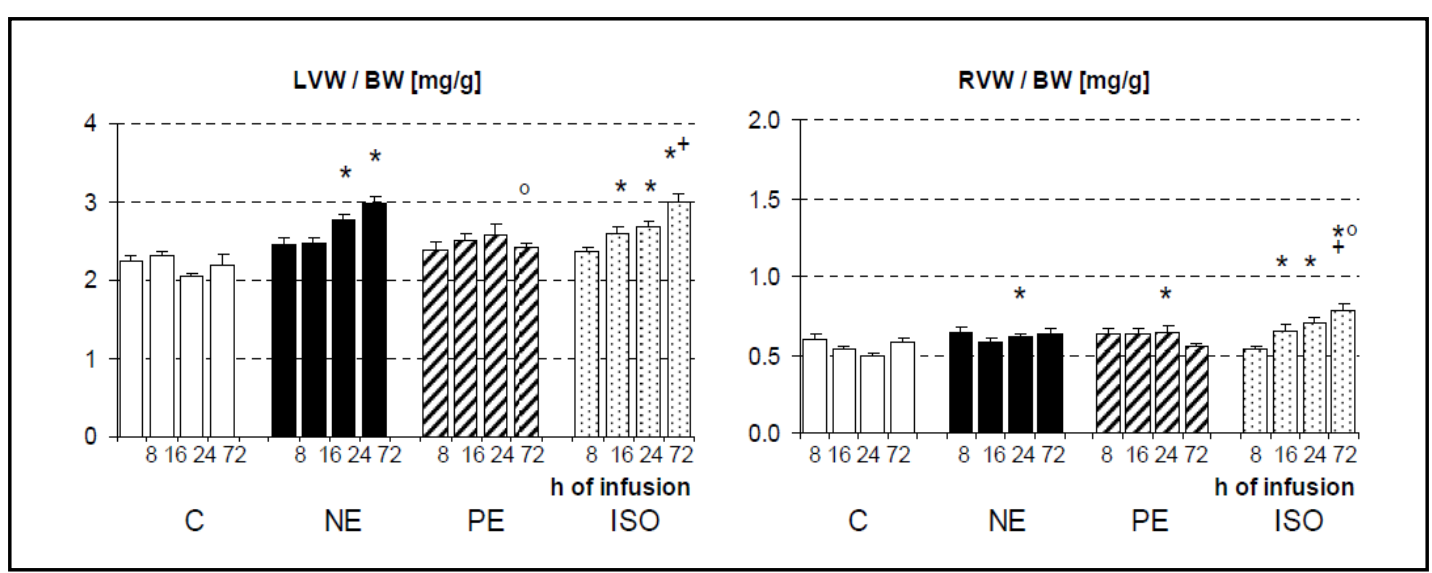

Fig. 7. Cardiac hypertrophy (only data from the main animal group are presented): left (LVW/BW) and right ventricular weight related to body weight (RVW/BW); animals were infused over 8, 16, 24 or $72 \mathrm{~h}$ with $\mathrm{NaCl}$ (control, $\mathrm{C} ; \mathrm{n}=6,6,5,5$ for 8, 16, 24 and $72 \mathrm{~h}$, respectively), norepinephrine (NE; $\mathrm{n}=4,6,6$, 7), phenylephrine (PE; $n=5,4,4,5$ ) or isoproterenol (ISO; $n=4,4,4,5$ ). Data are given in $\mathrm{mg} / \mathrm{g}$ (means + SEM). Statistic results and significance marks: ANOVA: $\mathrm{P}<0.001$ for LVW/BW and RVW/BW; * significant vs. time-corresponding $\mathrm{C}$; ${ }^{\circ}$ ISO and PE significant vs. time-corresponding $\mathrm{NE}$; ${ }^{+}$ISO significant vs. timecorresponding PE.

of infusion ( $0.82 \pm 0.26$ vs. $0.43 \pm 0.03 \mathrm{mmHg}$ min $\mathrm{kg} \mathrm{ml}^{-1}$; $\mathrm{P}<0.001$; Fig. 6f). PE had similar effects as NE on LVSP, DAP, CI and TPR. No significant differences were observed after $72 \mathrm{~h}$ of infusion with NE+PR compared to PE (LVSP $121 \pm 11$ vs. $133 \pm 7$ mmHg; RVSP $35 \pm 2$ vs. 39 $\pm 3 \mathrm{mmHg}$; CI $186 \pm 32$ vs. $229 \pm 8 \mathrm{ml} \mathrm{min}^{-1} \mathrm{~kg}^{-1}$; TPR $0.61 \pm 0.13$ vs. $0.53 \pm 0.03 \mathrm{mmHg} \mathrm{min}$ $\mathrm{kg} \mathrm{ml}^{-1}$; data not shown). 
Moreover, ISO induced hypertrophy of LV and RV emerging after $24 \mathrm{~h}$ and further rising after $72 \mathrm{~h}$ of stimulation up to more than $135 \%$ of C. A similar effect was obtained with $72 \mathrm{~h}$ of infusion with NE+PZ (LVW/BW $2.77 \pm 0.01$ vs. $2.99 \pm 0.10$ with ISO; RVW/BW $0.75 \pm 0.01$ vs. $0.79 \pm 0.04$ with ISO). NE induced LV hypertrophy of similar extent but no RV hypertrophy thus confirming previous results $[23,25]$. PE infusion did not cause cardiac hypertrophy (Fig. 7). Likewise, $72 \mathrm{~h}$ of infusion with NE+PR had no hypertrophic effect (LVW/BW 2.45 \pm 0.08 vs. $2.42 \pm 0.06$ with PE; RVW/BW $0.59 \pm 0.03$ vs. $0.56 \pm 0.02$ with PE). All changes in relative heart weight were due to genuine gains in ventricular weights as body weights did not significantly differ among groups ranging from 234 ( $24 \mathrm{~h} \mathrm{C})$ to $254 \mathrm{~g} \mathrm{(72} \mathrm{h} \mathrm{C).}$

\section{Discussion}

In the present study, we demonstrated for the first time enhanced pulmonary mRNA expression of ECM components such as Coll1, MMP-2 and its specific inhibitor TIMP-2, and of TGF- $\beta$ isoforms in rats after continuous infusion with adrenergic substances over $72 \mathrm{~h}$. Stimulation with NE induced a significant increase in the mRNA expression of Coll1 indicating enhanced synthesis and deposition of collagen fibers in the lung interstitium. Moreover, mRNA expression of MMP-2 and TIMP-2 were also increased (s. Fig. 2). In previous studies, we demonstrated occurrence of pulmonary edema and inflammation after 8-24 h of infusion $[4,5]$. Pulmonary edema was associated with pleural effusion [3] that is considered to serve as a protective draining mechanism to prevent alveolar flooding [26]. This injury developed most rapidly and most severely with $\alpha$-adrenergic stimulation induced with the $\alpha$-adrenergic agonist PE or with a combination of NE and the $\beta$-adrenergic antagonist propranolol [4]. Pulmonary edema and pleural effusion were also confirmed by our present results. After 72 $\mathrm{h}$ of CA infusion, edema had largely disappeared, and we found beginning peribronchial and interstitial fibrosis and mild vascular hypertrophy (see Fig. 1). Symptoms and time course of this CA-induced lung injury resembled human ALI or ARDS.

Role of TGF- $\beta$, MMP-2 and TIMP-2 in the development of pulmonary fibrosis

TGF- $\beta$ is an important mediator in fibrotic disorders by enhancing ECM synthesis and inhibiting ECM degradation. TGF- $\beta$ isoforms stimulate fibroblasts to produce greater amounts of collagen and other ECM components. They increase the number of fibroblasts by promoting the transition of pulmonary epithelial cells into fibroblasts and their proliferation $[27,28]$. Moreover, they down-regulate MMP-2 synthesis $[29,30]$ and stimulate TIMP expression [31], thus inhibiting degradation of the ECM.

Our present data showed significantly increased pulmonary mRNA expressions of TGF- $\beta_{1}$ and TGF- $\beta_{3}$ after $72 \mathrm{~h}$ of NE infusion (Fig. 3). These two TGF- $\beta$ isoforms had been demonstrated to increase TIMP-1 protein expression and to reduce secretion of MMP-1 and thus, to induce a significant increase in secreted and deposited collagen levels in human lung fibroblasts [16]. In a rat model of pulmonary inflammation and fibrosis, TGF- $\beta_{1}$ protein concentration increased at day 7 after bleomycin administration and then suppressed further up-regulation of MMP-2 synthesis [30]. Enhanced mRNA expression of TGF- $\beta_{3}$ and mainly, of TGF- $\beta_{1}$ was also found in experimental mouse models of lung fibrosis as well as in lung tissue from patients with fibrotic lung diseases, suggesting a predominant role of TGF- $\beta_{1}$ in the pathogenesis of pulmonary fibrosis $[17,27,32]$.

MMPs and TIMPs are important regulators of the balance between synthesis and degradation of ECM. MMP-2 degrades denatured collagens (gelatin) but also native type IV collagen, a specific constituent of basement membranes. Thus it plays an essential role in the remodeling of pulmonary basement membranes that occurs in various fibrotic and inflammatory lung diseases [33-36]. Disruption of the basement membrane is often followed by abnormal alveolar re-epithelization and invasion of fibroblasts and myofibroblasts into the alveolar space $[37,38]$. TIMP-2 is the natural MMP-2 inhibitor that reduces ECM degradation and induces proliferation. Hence, it is considered to promote stable ECM deposition and 
irreversible structural remodeling in the lung $[33,37]$. However, TIMP-2 is often co-regulated and co-expressed with MMP-2 [39] and, at low to moderate concentrations, activates MMP-2 [40]. In fibrotic diseases of the lung such as idiopathic pulmonary fibrosis, MMP-2 and TIMP2 are up-regulated in common, thus contributing to aberrant ECM remodeling which is a key feature of any fibrotic disorder [38].

Elevated concentrations of MMP-2 or TIMP-2 have been found in bronchoalveolar lavage fluid of ARDS patients [35, 41, 42] but also in animal models of experimental lung injury, e.g. by LPS exposure [43] or subacute hyperoxia [34]. The latter group reported increased pulmonary expression of MMP-2 mRNA from the third day on, corresponding to the time course in our study [34]. The results of the present study showing increased expression of TGF- $\beta$ isoforms, MMP- 2 and TIMP- 2 as well as beginning fibrosis in the lungs after 3 days of stimulation are in accordance with those findings.

\section{Effect of adrenergic stimulation on TGF- $\beta$ isoforms, MMP-2, TIMP-2 and collagen}

Previous studies demonstrated enhanced expression of TGF- $\beta$, MMP-2, TIMP- 2 and collagen in the rat heart after CA infusion. This was considered to result from direct stimulation of cardiac adrenoceptors rather than from hypertension [21]. This may also be valid in the lung. In experimental hypertension models, cardiacfibrosis developed notonly in the hypertrophied $\mathrm{LV}$, but also in the normotensive RV [44]. Moreover, adrenergic blockade, particularly $\alpha_{1}$-adrenoceptor blockade, reduced the NE-induced elevation of all the above-mentioned ECM molecules [45]. Finally, expression of MMP-2 and TIMP-2 mRNA remained elevated when the NE-induced afterload increase was normalized with nisoldipin [21].

Studies on the rat heart showed that NE increased mRNA expression of all three TGF- $\beta$ isoforms but with differential time courses. While TGF- $\beta_{2}$ mRNA peaked after $12 \mathrm{~h}$ of infusion, TGF- $\beta_{1}$ mRNA started to increase after two days. After 3-4 days of NE infusion, a significant elevation of TGF- $\beta_{2}$ protein concentration was observed. TGF- $\beta_{1}$ protein concentration was expected to increase beyond this period [45] since after $14 \mathrm{~d}$ of NE stimulation enhanced collagen deposition in the heart had been shown [21]. Our present results demonstrate a similar time course of TGF- $\beta$ isoform mRNA expression after NE infusion in lung tissue (cf. Fig. 4). While TGF- $\beta_{2}$ protein showed a significant increase within 3 days of PE and ISO infusion, TGF- $\beta_{1}$ did not (cf. Fig. 5). According to the aforementioned findings in rat heart, we would expect TGF- $\beta_{1}$ protein to increase after a longer period of stimulation and to further promote development of fibrosis in the lung. This time course would also correspond to data from a rat model of a bleomycin-induced lung injury [30].

TGF- $\beta$ mRNA expression in the lung was more pronounced with PE than with NE or with ISO (cf. Fig. 4). This is in accordance with findings in other tissues. In cultured human smooth muscle cells, TGF- $\beta_{1}$ mRNA expression and collagen protein production were increased by $\alpha_{1}$-adrenergic stimulation with phenylephrine [46]. In the rat heart, Briest and co-workers demonstrated an almost complete blockade of the NE-induced elevation of TGF- $\beta$ mRNA expression by addition of the $\alpha_{1}$-adrenergic antagonist prazosin but not with the $\beta_{1}$-adrenergic blocker metoprolol [45].

Coll1, Coll3, MMP-2 and TIMP-2 mRNA expression as well as the concentration of active MMP-2 protein were also significantly increased in the rat heart after 3-4d of NE infusion [45, 47]. This increase was significantly reduced in combination with prazosin or with metoprolol [45]. In cultured cardiac myocytes, application of TGF- $\beta$ plus NE exerted an hypertrophic effect that was reduced by addition of the $\beta$-adrenergic blocker propranolol, but even more by $\alpha_{1}$-adrenergic blockade with prazosin [20]. These results suggest that profibrotic CA effects are mediated by both $\alpha$ - and $\beta$-adrenoceptor stimulation with $\alpha$-adrenergic effects being predominant. This is also reflected by the present results obtained in the lung (cf. Fig. 2 and 3 ) including the histological degree of pulmonary fibrosis. Even though fibrosis was just in its initial stage after $72 \mathrm{~h}$, it was most pronounced in NE-treated animals and was milder after stimulation with selective $\alpha$ - and $\beta$-adrenergic agonists (PE and ISO, respectively) or infusion of NE combined with $\alpha$ - and $\beta$-adrenergic blockers (PZ and PR, respectively; cf. Fig. 1). 
We had previously demonstrated that CA infusion, particularly $\alpha$-adrenergic stimulation, induced pulmonary injury with edema and inflammation [4]. The present data show that this injury is accompanied by transition into pulmonary fibrosis - a pathogenic pattern resembling ALI or ARDS in humans. Severe inflammatory reactions as one of the central features in the pathogenesis of ALI and ARDS are closely linked to transition into fibrosis. Central sympathetic activation or elevated levels of circulating NE are often associated with the etiologic condition and have repeatedly been suggested to contribute to the development of ALI/ARDS $[1,2]$. We had previously found that both $\alpha$ - and $\beta$-adrenergic stimulation induced pulmonary inflammation [4]. We would suggest that these proinflammatory effects are strongly related to the profibrotic processes observed in the present study.

\section{Cardiac function and hypertrophy}

Adrenergic stimulation affected hemodynamic function and hypertrophy of LV and RV in a differential way. NE significantly increased HR and RVSP but not LVSP. Short-term infusion with ISO had a similar effect while PE infusion did not alter cardiac function. In a previous study, Irlbeck and co-workers investigated hemodynamic effects of $\mathrm{NE}$ in various doses $\left(0.05,0.1\right.$, and $\left.0.2 \mathrm{mg} \mathrm{kg}^{-1} \mathrm{~h}^{-1}\right)$. They observed that LVSP was only elevated with 0.05 mg kg-1 $\mathrm{h}^{-1}$ and decreased with higher NE doses while RVSP increased in parallel with the NE dose. Contractility and heart rate were significantly increased with all three NE doses. The authors assumed that the differential response of LV and RV might be due to a different distribution of $\alpha$ - and $\beta$-adrenoceptors in the ventricles [22].

On the other hand, hypertrophy is mainly a $\beta$-adrenergic effect $[20,23,48]$. Leicht and colleagues used the same drugs and doses as we did in the present study. They found that only $\beta$-adrenergic stimulation (with $0.024 \mathrm{mg} \mathrm{kg}^{-1} \mathrm{~h}^{-1}$ ISO or with a combination of 0.1 $\mathrm{mg} \mathrm{kg}^{-1} \mathrm{~h}^{-1} \mathrm{NE}$ plus $\left.0.1 \mathrm{mg} \mathrm{kg}^{-1} \mathrm{~h}^{-1} \mathrm{PZ}\right)$ but not NE or $\alpha$-adrenergic stimulation $\left(0.5 \mathrm{mg} \mathrm{kg}^{-1}\right.$ $\mathrm{h}^{-1} \mathrm{PE}$ or NE combined with $1.0 \mathrm{mg} \mathrm{kg}^{-1} \mathrm{~h}^{-1} \mathrm{PR}$ ) induced RV hypertrophy [23]. The results of our present study are in full accordance with these and other findings showing most pronounced hypertrophy both in LV and RV after 72h of ISO infusion while NE only induced LV hypertrophy [21, 25].

Adrenoceptor stimulation also exerts myocardial injury and fibrosis but these are independent of myocardial hypertrophy [48]. Taken together, these findings suggest that cardiac hypertrophy is predominantly a direct adrenergic effect, probably mediated via IL-6dependent pathways $[23,49]$. It is also not primarily due to pulmonary fibrosis as this would result in a predominant RV hypertrophy after infusion of all three types of CAs, particularly of $\alpha$-adrenergic agonists. However, pulmonary fibrosis and its hemodynamic consequences might aggravate RV hypertrophy as suggested by previous results with $14 \mathrm{~d}$ of NE stimulation [21].

\section{Conclusions}

Continuous infusion with adrenergic agonists over three days increased mRNA expression of ECM molecules such as Coll1, MMP-2, TIMP-2, and of TGF- $\beta$ isoforms in the rat lung. Consequently, lung histology presented first signs of developing pulmonary fibrosis. We assume that these profibrotic processes are strongly related to the proinflammatory effects of adrenergic stimulation. Both $\alpha$ - and $\beta$-adrenergic pathways are involved in the development of fibrosis but $\alpha$-adrenergic stimulation is more effective. In contrast, cardiac hypertrophy is predominantly mediated by $\beta$-adrenergic receptor stimulation and hence, is considered to be a direct effect on the heart and not a consequence of stimulation of cardiac or pulmonary ECM proteins. 


\begin{tabular}{|c|c|c|}
\hline Cellular PI & Cell Physiol Biochem 2012;30:1134-1147 & \\
\hline and Biochemistry & $\begin{array}{l}\text { DOI: } 10.1159 / 000343304 \\
\text { Published online: October 05, } 2012\end{array}$ & $\begin{array}{l}\text { O } 2012 \text { S. Karger AG, Basel } \\
\text { www.karger.com/cpb }\end{array}$ \\
\hline
\end{tabular}

\section{Acknowledgements}

We gratefully appreciate the valuable technical assistance of Mrs. Brigitte Mix and Mrs. Ursula Vogt. This work was supported by the Deutsche Forschungsgemeinschaft (ZI 199/10-4).

\section{Conflict of Interest}

The authors declare that there are no conflicts of interest.

\section{References}

1 Dincer HE, Gangopadhyay N, Wang R, Uhal BD: Norepinephrine induces alveolar epithelial apoptosis mediated by alpha-, beta-, and angiotensin receptor activation. Am J Physiol Lung Cell Mol Physiol 2001;281:L624-L630.

2 Chen HI, Kao SJ, Wang D, Lee RP, Su CF: Acute respiratory distress syndrome. J Biomed Sci 2003;10:588592.

-3 Rassler B, Barth W, Zimmer HG: Transient pleural effusion in norepinephrine-stimulated rats. Basic Res Cardiol 2001;96:471-477.

-4 Rassler B, Reissig C, Briest W, Tannapfel A, Zimmer HG: Catecholamine-induced pulmonary edema and pleural effusion in rats - alpha- and beta-adrenergic effects. Respir Physiol Neurobiol 2003;135:25-37.

-5 Rassler B, Rohling MA, Reissig C, Briest W, Tannapfel A, Zimmer HG: Involvement of cytokines and inflammation in catecholamine-induced pulmonary injury in rats. Vascular Disease Prevention 2005;2:1-9.

6 Pugin J, Verghese G, Widmer MC, Matthay MA: The alveolar space is the site of intense inflammatory and profibrotic reactions in the early phase of acute respiratory distress syndrome. Crit Care Med 1999;27:304312.

7 Marshall RP, Bellingan G, Webb S, Puddicombe A, Goldsack N, McAnulty RJ, Laurent GJ: Fibroproliferation occurs early in the acute respiratory distress syndrome and impacts on outcome. Am J Respir Crit Care Med 2000;162:1783-1788.

8 Bellingan GJ: The pulmonary physician in critical care - 6: The pathogenesis of ALI/ARDS. Thorax 2002;57:540-546.

-9 Olman MA, White KE, Ware LB, Cross MT, Zhu S, Matthay MA: Microarray analysis indicates that pulmonary edema fluid from patients with acute lung injury mediates inflammation, mitogen gene expression, and fibroblast proliferation through bioactive interleukin-1. Chest 2002;121:69S-70S.

$>10$ Delclaux C, d'Ortho MP, Delacourt C, Lebargy F, Brun-Buisson C, Brochard L, Lemaire F, Lafuma C, Harf A: Gelatinases in epithelial lining fluid of patients with adult respiratory distress syndrome. Am J Physiol Lung Cell Mol Physiol 1997;272:L442-L451.

11 Torii K, Iida K, Miyazaki Y, Saga S, Kondoh Y, Taniguchi H, Taki F, Takagi K, Matsuyama M, Suzuki R: Higher concentrations of matrix metalloproteinases in bronchoalveolar lavage fluid of patients with adult respiratory distress syndrome. Am J Respir Crit Care Med 1997;155:43-46.

12 Matrisian LM: Metalloproteinases and their inhibitors in matrix remodeling. Trends Genet 1990;6:121125.

13 Sternlicht MD, Werb Z: How matrix metalloproteinases regulate cell behaviour. Annu Rev Cell Dev Biol 2001;17:463-516.

14 Hall MC, Young DA, Waters JG, Rowan AD, Chantry A, Edwards DR, Clark IM: The Comparative Role of Activator Protein 1 and Smad Factors in the Regulation of Timp-1 and MMP-1 Gene Expression by Transforming Growth Factor- $\beta 1$. J Biol Chem 2003;278:10304-10313.

15 Martin-Chouly CA, Astier A, Jacob C, Pruniaux MP, Bertrand C, Lagente V: Modulation of matrix metalloproteinase production from human lung fibroblasts by type 4 phosphodiesterase inhibitors. Life Sci 2004;75:823-840. 


\section{Cellular Physiology $\quad$ Cell Physiol Biochem 2012;30:1134-1147 and Biochemistry

16 Eickelberg 0, Köhler E, Reichenberger F, Bertschin S, Woodtli T, Erne P, Perruchoud AP, Roth M: Extracellular matrix deposition by primary human lung fibroblasts in response to TGF- $\beta 1$ and TGF- $\beta 3$. Am J Physiol Lung Cell Mol Physiol 1999;276:L814-L824.

17 Coker RK, Laurent GJ, Jeffery PK, du Bois RM, Black CM, McAnulty RJ: Localisation of transforming growth factor beta1 and beta3 mRNA transcripts in normal and fibrotic human lung. Thorax 2001;56:549-556.

18 Tsuruda T, Costello-Boerrigter LC, Burnett JC Jr: Matrix metalloproteinases: pathways of induction by bioactive molecules. Heart Fail Rev 2004;9:53-61.

19 Bhambi B, Eghbali M: Effect of norepinephrine on myocardial collagen gene expression and response of cardiac fibroblasts after norepinephrine treatment. Am J Pathol 1991;139:1131-1142.

20 Akiyama-Uchida Y, Ashizawa N, Ohtsuru A, Seto S, Tsukazaki T, Kikuchi H, Yamashita S, Yano K: Norepinephrine Enhances Fibrosis Mediated by TGF- $\beta$ in Cardiac Fibroblasts. Hypertension 2002;40:148154.

21 Briest W, Hölzl A, Rassler B, Deten A, Leicht M, Baba HA, Zimmer HG: Cardiac remodeling after long term norepinephrine treatment in rats. Cardiovasc Res 2001;52:265-273.

22 Irlbeck M, Zimmer HG: Functional responses of the left and right heart of diabetic rats to alpha- and betaadrenergic receptor stimulation. Diabetes Res Clin Pract 1996;31:S79-86.

23 Leicht M, Greipel N, Raßler B, Zimmer HG: Catecholamine-induced cardiac hypertrophy in rats is associated with the activation of p70S6 kinase and c-Jun NH2-terminal kinase 2. Exp Clin Cardiol 2002;7:131-137.

24 Tyagi SC, Matsubara L, Weber KT: Direct extraction and estimation of collagenase(s) activity by zymography in microquantities of rat myocardium and uterus. Clin Biochem 1993;26:191-198.

25 Irlbeck M, Mühling 0, Iwai T, Zimmer HG: Different response of the rat left and right heart to norepinephrine. Cardiovasc Res 1996;31:157-162.

26 Staub NC: New concepts about the pathophysiology of pulmonary edema. J Thorac Imaging 1988;3:8-14.

-27 Kim KK, Kugler MC, Wolters PJ, Robillard L, Galvez MG, Brumwell AN, Sheppard D, Chapman HA: Alveolar epithelial cell mesenchymal transition develops in vivo during pulmonary fibrosis and is regulated by the extracellular matrix. Proc Natl Acad Sci USA 2006;103:13180-13185.

28 McAnulty RJ: Fibroblasts and myofibroblasts: their source, function and role in disease. Int J Biochem Cell Biol 2007;39:666-671.

29 Risinger GM, Updike DL, Bullen EC, Tomasek JJ, Howard EW: TGF-beta suppresses the upregulation of MMP-2 by vascular smooth muscle cells in response to PDGF-BB. Am J Physiol Cell Physiol 2010;298:C191201.

30 Ye H, Cai PC, Zhou Q, Ma WL: Transforming growth factor-beta1 suppresses the up-regulation of matrix metalloproteinase- 2 by lung fibroblasts in response to tumor necrosis factor-alpha. Wound Rep Reg 2011;19:392-399.

-31 Edwards DR, Murphy G, Reynolds JJ, Whitham SE, Docherty AJ, Angel P, Heath JK: Transforming growth factor beta modulates the expression of collagenase and metalloproteinase inhibitor. EMBO J 1987;6:18991904.

-32 Coker RK, Laurent GJ, Shahzeidi S, Lympany PA, du Bois RM, Jeffery PK, McAnulty RJ: Transforming growth factors-beta 1 , -beta 2 , and -beta 3 stimulate fibroblast procollagen production in vitro but are differentially expressed during bleomycin-induced lung fibrosis. Am J Pathol 1997;150:981-991.

-33 Fukuda Y, Ishizaki M, Kudoh S, Kitaichi M, Yamanaka N: Localization of Matrix Metalloproteinases-1, -2, and -9 and Tissue Inhibitor of Metalloproteinase-2 in Interstitial Lung Diseases. Lab Invest 1998;78:687-698.

-34 Pardo A, Barrios R, Maldonado V, Meléndez J, Pérez J, Ruiz V, Segura-Valdez L, Sznajder JI, Selman M: Gelatinases A and B Are Up-Regulated in Rat Lungs by Subacute Hyperoxia. Pathogenetic Implications. Am J Pathol 1998;153:833-844.

-35 Corbel M, Boichot E, Lagente V: Role of gelatinases MMP-2 and MMP-9 in tissue remodeling following acute lung injury. Braz J Med Biol Res 2000;33:749-754.

-36 Corbel M, Belleguic C, Boichot E, Lagente V: Involvement of gelatinases (MMP-2 and MMP-9) in the development of airway inflammation and pulmonary fibrosis. Cell Biol Toxicol 2002;18:51-61.

37 Selman M, Ruiz V, Cabrera S, Segura L, Ramirez R, Barrios R, Pardo A: TIMP-1, -2, -3, and -4 in idiopathic pulmonary fibrosis. A prevailing nondegradative lung microenvironment? Am J Physiol Lung Cell Mol Physiol 2000;279:562-574. 


\section{Cellular Physiology $\quad$ Cell Physiol Biochem 2012;30:1134-1147 and Biochemistry

-38 Pardo A, Selman M: Idiopathic pulmonary fibrosis: new insights in its pathogenesis. Int J Biochem Cell Biol 2002;34:1534-1538.

-39 Lohi J, Lehti K, Valtanen H, Parks WC, Keski-Oja J: Structural analysis and promoter characterization of the human membrane-type matrix-metalloproteinase-1 (MT1-MMP) gene. Gene 2000;242:75-86.

-40 Strongin AY, Collier I, Bannikov G, Marmer BL, Grant GA, Goldberg GI: Mechanism of cell surface activation of 72-kDa type IV collagenase. Isolation of the activated form of the membrane metalloprotease. J Biol Chem 1995;270:5331-5338.

-41 Fligiel SE, Standiford T, Fligiel HM, Tashkin D, Strieter RM, Warner RL, Johnson KJ, Varani J: Matrix metalloproteinases and matrix metalloproteinase inhibitors in acute lung injury. Hum Pathol 2006;37:422430.

42 Lin WC, Lin CF, Chen CL, Chen CW, Lin YS: Prediction of outcome in patients with acute respiratory distress syndrome by bronchoalveolar lavage inflammatory mediators. Exp Biol Med 2010;235:57-65.

-43 D’Ortho MP, Jarreau PH, Delacourt C, Macquin-Mavier I, Levame M, Pezet S, Harf A, Lafuma C: Matrix metalloproteinase and elastase activities in LPS-induced acute lung injury in guinea pigs. Am J Physiol 1994;266:L209-L216.

44 Brilla CG, Pick R, Tan LB, Janicki JS, Weber KT: Remodeling of the rat right and left ventricles in experimental hypertension. Circ Res 1990;67:1355-1364.

45 Briest W, Homagk L, Rassler B, Ziegelhöffer-Mihalovicová B, Meier H, Tannapfel A, Leiblein S, Saalbach A, Deten A, Zimmer HG: Norepinephrine-induced changes in cardiac transforming growth factor-beta isoform expression pattern of female and male rats. Hypertension 2004;44:410-418.

-46 O'Callaghan CJ, Williams B: The regulation of human vascular smooth muscle extracellular matrix protein production by alpha- and beta-adrenoceptor stimulation. J Hypertens 2002;20:287-294.

$\checkmark 47$ Briest W, Hölzl A, Rassler B, Deten A, Baba HA, Zimmer HG: Significance of matrix metalloproteinases in norepinephrine-induced remodelling of rat hearts. Cardiovasc Res 2003;57:379-387.

-48 Allard MF, DeVenny MF, Doss LK, Grizzle WE, Bishop SP: Alterations in dietary sodium affect isoproterenolinduced cardiac hypertrophy. J Mol Cell Cardiol 1990;22:1135-1145.

-49 Meier H, Bullinger J, Marx G, Deten A, Horn LC, Rassler B, Zimmer HG, Briest W: Crucial role of interleukin6 in the development of norepinephrine-induced left ventricular remodeling in mice. Cell Physiol Biochem 2009;23:327-334. 